\title{
Grass Response Following Thinning of Broom Snakeweed
}

\author{
KIRK C. MCDANIEL, REX D. PIEPER, AND GARY B. DONART
}

\section{Abstract}

Complete removal of broom snakeweed resulted in perennial grass production $833 \%$ of that on untreated rangeland after one growing season, and $712 \%$ and $300 \%$ the second and third year, on a pasture heavily grazed and in poor range condition. On a moderately grazed pasture in good range condition, grass standing crop increased $42 \%$ the first year, $81 \%$ the second, and $25 \%$ the third compared to untreated rangeland. Perennial grass production on the heavily grazed pasture was far below that on the moderately grazed pasture at the start of the study ( $40 \mathrm{vs} 454 \mathrm{~kg} / \mathrm{ha}$ ). After 3 years, with complete broom snakeweed removal and no grazing, perennial grass production was comparable on the pastures once heavily and moderately grazed (1014 vs $939 \mathrm{~kg} / \mathrm{ha}$, respectively).

Broom snakeweed (Xanthocephalum sarothrae) is a serious perennial weed problem on rangeland in New Mexico. The problem is two-pronged in that, under some conditions, broom snakeweed is poisonous, causing abortion in cattle (Sperry and Robinson 1963), and the weed competes with more valuable forage plants (Ueckert 1979). Platt (1959) estimated that species of the genus Gutierrezia (since treated as Xanthocephalum. Correll and Johnson 1970) occurred on more than $\mathbf{3 5 0}$ million ha of rangeland in the United States. Broom snakeweed is native on about $60 \%$ of New Mexico rangelands.

Broom snakeweed populations have increased and subsequently decreased in a cyclic pattern at the Fort Stanton Experimental Ranch in New Mexico following droughts in 1970-71, 1974, and 1976 (Pieper and Donart 1973). Above-average fall, winter, and spring precipitation following drought years appears to be related to the establishment of broom snakeweed on the blue grama (Bouteloua gracilis) range.

Since some studies (Jameson 1970, Vallentine 1971) and observations indicate that broom snakeweed populations are cyclic, it seems logical to assume that these plants are fairly short lived. Dittberner (1971) analyzed permanent quadrat records from the Jornada Experimental Range in southern New Mexico collected over a 53-year period and found the average life span of all age classes of snakeweed to be about 2.5 years. Dittberner determined that nearly $70 \%$ of the broom snakeweed seedlings die in the first year. Plants living beyond the first year were found to have an a verage life span of a bout 4 years. Longevity of the oldest plants ranged up to 15 years.

Mature broom snakeweed begins its seasonal growth in late winter to early spring in the Southwest (Ragsdale 1969). Dormant buds, developed in a band above and below the root crown, initiate growth earlier than associated grasses. Because of the competitive advantage from this early growth, there is evidence that production of perennial grasses is decreased where broom snakeweed densities are high. Ueckert (1979) reported herbage production on short grass range to be severely reduced under a dense stand of broom snakeweed. When Ueckert reduced broom snakeweed by 25 and

\footnotetext{
Authors are assistant professor, professor, and professor, Department of Animal and Range Sciences, New Mexico State University, Las Cruces.

This report was submitted as Journal Article 793, Agricultural Experiment Station. New Mexico State University, Las Cruces 88003.

Manuscript received July 27, 1980.
}

$50 \%$, there was no effect on grass production. However, when all broom snakeweed plants were removed, grass production increased $107 \%$.

Broom snakeweed apparently undergoes intraspecific competition as well as interspecific competition with other species (Ueckert 1979). The degree of competition appears dependent upon the population density and the competitive ability of associated species. The objective of this study was to investigate the response of associated species to the removal of broom snakeweed competition.

\section{Study Area and Procedures}

The study was conducted on the Fort Stanton Experimental Ranch $6 \mathrm{~km}$ east of Capitan, New Mexico. Average annual precipitation is about $39 \mathrm{~cm}$, with over $60 \%$ falling from June through September. Open grasslands on mesas and plateaus are dominated by blue grama. Woodlands occupy steep slopes and rugged hills and are dominated by pinyon and juniper (Pinus edulis and Juniperus monosperma) and wavy-leaf oak (Quercus undulata). Elevation on the ranch varies between 1950 and $2250 \mathrm{~m}$.

Two locations selected in 1977 on the Fort Stanton Station represented areas under different grazing intensities and range condition. One area was located in a pasture continuously grazed year-long since 1969 at a heavy stocking rate ( $18.9 \mathrm{ha} / \mathrm{AU})$. This pasture was considered to be in poor range condition. The second location was in a moderately grazed pasture ( $23 \mathrm{ha} / \mathrm{AU})$ in good range condition that had also been grazed since 1969 . The soil at both locations is from the Dioxice loam series, which is classified as a fine loamy mixed mesic aridic calciustoll.

In May 1977 fences were constructed to exclude grazing from a 0.1 -ha area in each of the two pastures. The fenced areas encompassed a relatively homogeneous stand of 1-year-old broom snakeweed plants. Broom snakeweed density was determined by counting all plants within $9 \mathrm{~m}^{2}$ plots, calculating a mean for the exclosure, then uniformly thinning the plants to a desired level by clipping at ground level. Broom snakeweed was reduced by 0,25 , 50,75 , or $100 \%$ of the mean density in the heavily grazed pasture, and by $0,33,50,67$, and $100 \%$ in the moderately grazed pasture. Treatments were replicated four times in a randomized complete block design at each location.

Basal cover and standing crop of grasses and forbs were determined annually in the fall at each location. Basal cover was determined by randomly placing a 10-point frame along 15 line transects in each plot and recording basal hits for broom snakeweed, forbs and perennial grasses. Herbage standing crop was determined for each species by clipping four $0.25 \mathrm{~m}^{2}$ quadrats in each plot at the end of the growing season. New areas were clipped each season during the 3-year study. All clipped vegetation was separated by species in the field and later oven-dried at $60^{\circ} \mathrm{C}$ for $72 \mathrm{hrs}$ before weighing. Basal cover and standing crop data were analyzed by analysis of variance. Duncan's multiple range tests were used to separate differences among means where appropriate. 
Table 1. Mean density (plants/ $\mathbf{m}^{2}$ ) of broom snakeweed after thinning plants in May 1977. Natural mortality further reduced the density of plants in 197 ; and 1979.

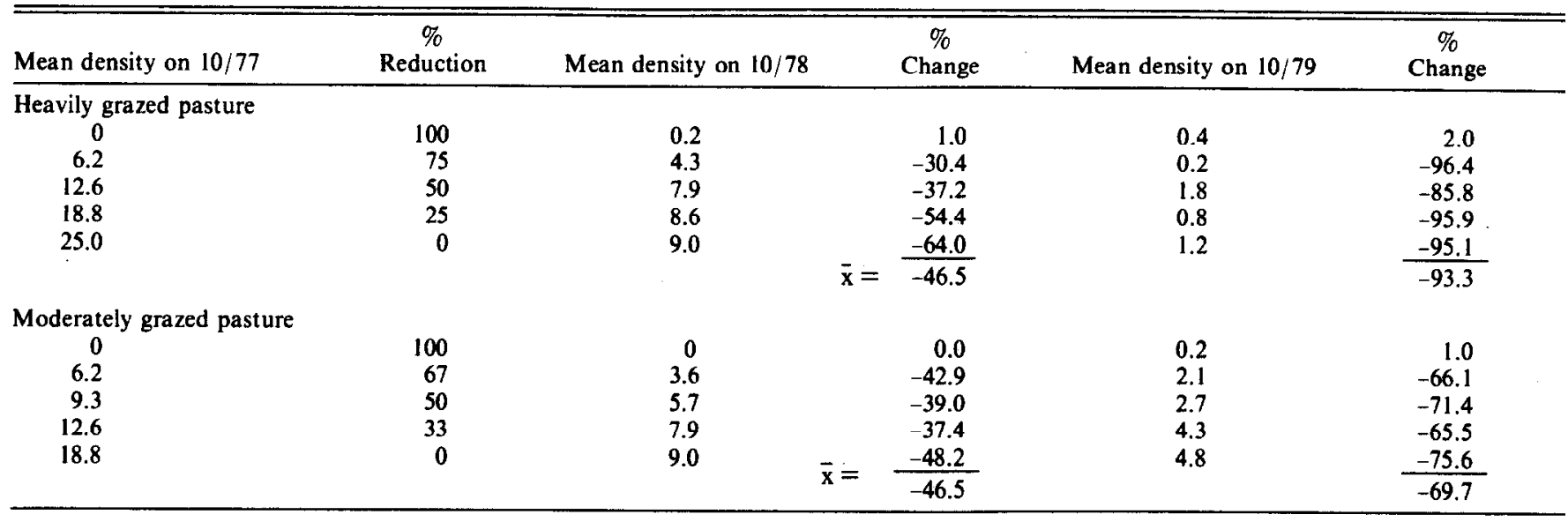

\section{Results and Discussion}

\section{Density and Mortality of Broom Snakeweed}

The original mean density of broom snakeweed was 25 plants $/ \mathrm{m}^{2}$ in the heavily grazed pasture, and 18.0 plants $/ \mathrm{m}^{2}$ in the moderately grazed pasture (Table 1). Natural mortality with little emergence of new broom snakeweed seedlings occurred in all treatments from 1977 to 1979 . There was no change in the number of broom snakeweed plants at the two locations from spring to fall 1977; however, by fall 1978 about $46.5 \%$ of the plants died at both locations. Mortality continued to increase into the fall 1979 where only $7 \%$ of the original plants were still alive in the heavily grazed pasture, and only $30 \%$ of the original plants remained in the moderately grazed pasture.

Mortality of broom snakeweed on the heavily grazed pasture from fall 1977 to 1978 ranged from $64 \%$ on plots not previously thinned to $54.4,37.2$, and $30.4 \%$ on plots thinned by 25,50 , and $75 \%$ of the original density, respectively (Table 1). Density counts taken from the moderately grazed pasture in 1977 and 1978 also showed mortality to be 5 to $10 \%$ higher on unthinned plots compared to areas where broom snakeweed was originally reduced by 33,50 , and $67 \%$. The lower mortality of broom snakeweed in plots that were thinned agree with Ueckert's (1979) observation that intraspecific competition within dense stands of broom snakeweed is severe but can be reduced by decreasing population density.

Few broom snakeweed seedlings emerged during the 3 year study. From spring 1977 to fall 1979 less than one new broom snakeweed seedling/ $\mathrm{m}^{2}$ was noted at both locations. There was no difference in emergence between the treatments. Precipitation during this period was near or above the 83-year annual average for the Fort Stanton Station (Table 2), and it is unknown why more seedling did not emerge.

\section{Basal Cover and Herbage Production}

Complete removal of broom snakeweed increased basal cover of perennial grasses 32 and $62 \%$ compared to untreated rangeland the first growing season after thinning in the moderate and heavily grazed pastures, respectively (Figs. 1 and 2 ). Grass cover was not affected where $75 \%$ or less of the broom snakeweed was removed the first year. Basal cover of grasses increased on most treatments the second and third years after treatment, probably due to further thinning of broom snakeweed by natural mortality, rest from grazing, and above-average precipitation.

Blue grama was a dominant grass at both study locations. Sideoats grama (Bouteloua curtipendula) was an important codominant on the heavily grazed pasture, whereas wolftail (Lycurus phleoides) was more important on the moderately grazed pasture. In the moderately grazed pasture, blue grama and wolftail had significantly $(P=0.05)$ greater basal cover the first growing season where all broom snakeweed was removed compared to the othe treatments (Fig. 1). In the second year, ba sal cover for these specie was about equal among treatments thinned by $50 \%$ or more and a exceeded the basal area on untreated rangeland. By the thir growing season after thinning the broom snakeweed, there was $\mathbf{n}$ difference in basal cover among treatments in the moderatel grazed pasture.

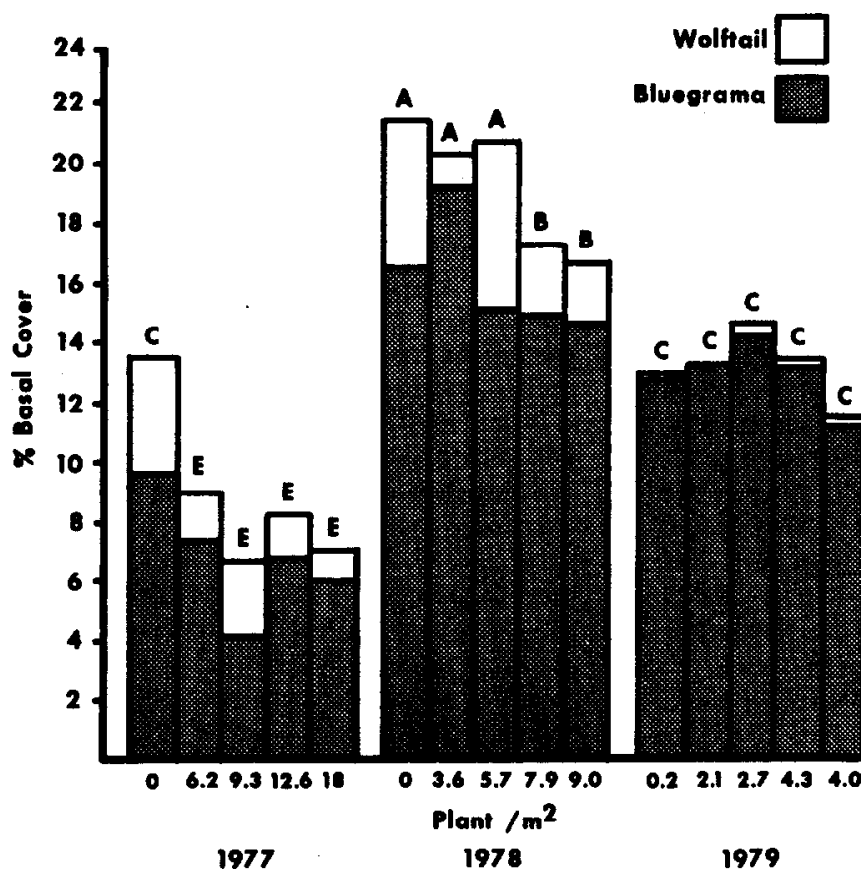

Fig. 1. Basal cover for blue grama and wolftail in a moderately grazea pasture in fall 1977 to 1979 following thinning of broom snakeweed in May 1977.

On the heavily grazed pasture, blue grama basal cover was equa on all treatments the first year but increased after the second and third years only on rangeland where broom snakeweed was thinned by more than $50 \%$ (Fig. 2). Blue grama basal cover did no1 differ among treatments thinned less than $50 \%$ throughout the study. Basal cover of sideoats grama in areas where broom snake. weed was completely removed exceeded that on all other treatments during each year of the study. Basal cover of sideoats grama in areas thinned by 75 or $50 \%$ was generally intermediate to those plots not thinned or reduced to $25 \%$ of the original broom snakeweed density. The release of blue grama and sideoats grama follow- 


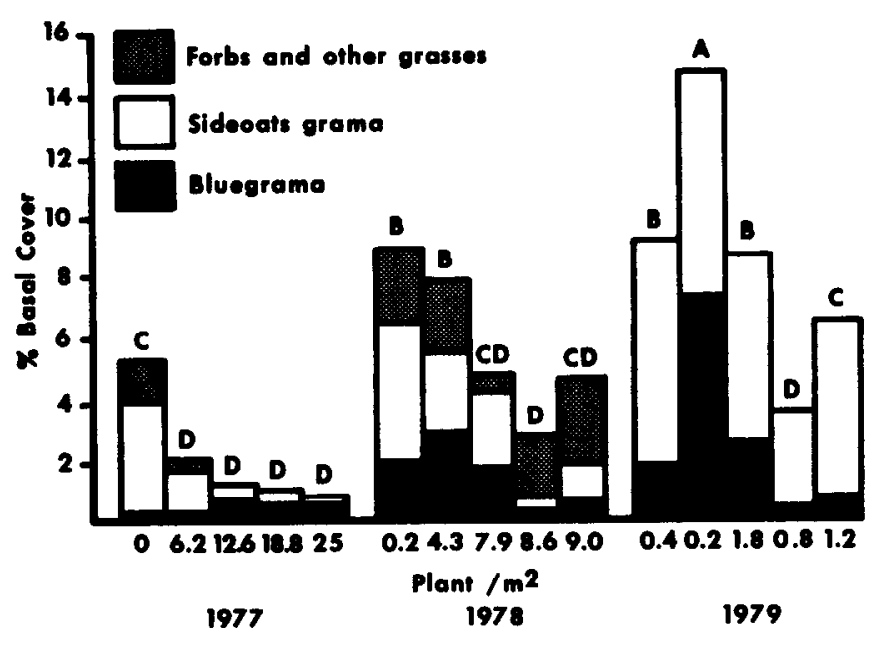

Fig. 2. Basal cover for blue grama, sideoats grama, and forbs in a heavily grazed pasture in fall 1977 to 1979 following thinning of broom snakeweed in May 1977.

ing the complete removal of broom snakeweed was more dramatic on the heavily grazed pasture than the moderately grazed pasture. This may be the result of the initial range condition in the pastures. The complete elimination of broom snakeweed resulted in an average $50 \%$ increase in basal cover of perennial grasses in the moderately grazed pasture, and a $89 \%$ increase in the heavily grazed pasture compared to untreated rangeland after 3 years.

Differences in standing crop of perennial grasses where broom snakeweed was completely or partially removed were generally analogous to basal cover responses. Standing crop of perennial grasses in both pastures was significantly greater $(P=0.05)$ during each year of the 3-year study where broom snakeweed was completely removed compared to untreated rangeland (Table 3 ).

In the heavily grazed pasture complete removal of broom snakeweed increased standing crop of perennial grasses $378 \mathrm{~kg} / \mathrm{ha}$ $(833 \%)$ and forbs $515 \mathrm{~kg} / \mathrm{ha}(1907 \%)$ compared to untreated rangeland after one growing season (Table 3 ). Reducing broom snakeweed to $75 \%$ of its original density also resulted in a significant increase in the standing crop of perennial grasses as compared to the untreated areas ( $169 \mathrm{~kg} /$ ha or $423 \%$ increase). Reducing broom snakeweed density by 25 or $50 \%$ did not affect grass or forb production the first year. By the third growing season, with less than $7 \%$ of the original broom snakeweed remaining in the heavily grazed pasture, because of natural mortality, grass production on the partially thinned areas $(25,50$ or $75 \%)$ was significantly above that on untreated rangeland but below that on areas where broom snakeweed was completely removed.

In the moderately grazed pasture, complete removal of broom snakeweed also increased standing crop of grasses and forbs the

Table 2. Monthly precipitation (cm) at Fort Stanton for 1977, 1978, 1979, and the 83 -year average.

\begin{tabular}{lcccc}
\hline \hline Month & 1977 & 1978 & 1979 & 83-yr avg. \\
\hline January & 1.3 & 3.0 & 3.2 & 1.43 \\
February & 1.2 & 0.9 & 1.9 & 1.2 \\
March & 0.5 & 0.5 & 0.3 & 1.5 \\
April & 3.6 & 0 & 0.3 & 1.4 \\
May & 1.1 & 3.3 & 4.8 & 2.2 \\
June & 3.9 & 4.7 & 6.7 & 3.1 \\
July & 12.8 & 5.4 & 9.3 & 7.9 \\
August & 4.5 & 9.6 & 9.4 & 6.8 \\
September & 3.4 & 6.4 & 3.5 & 4.8 \\
October & 0.6 & 6.4 & 0.6 & 1.9 \\
November & 0.5 & 6.1 & 0.6 & 0.7 \\
December & 0 & 1.3 & 2.3 & 1.7 \\
Annual total & 33.6 & 55.9 & 41.9 & 34.8 \\
\hline
\end{tabular}

Table 3. Standing crop ( $\mathrm{kg} / \mathrm{ha}$ ) of perennial grasses and forbs at two study locations from October 1977 to 1979 following thinning of broom snakeweed in May 1977. Natural mortality of broom snakeweed further reduced the density of plants in 1978 and 1979.

\begin{tabular}{|c|c|c|}
\hline $\begin{array}{l}\text { Broom snakeweed } \\
\text { density } \\
\left.\text { (plants } / \mathrm{m}^{2}\right)\end{array}$ & $\begin{array}{c}\text { Grass production } \\
(\mathrm{kg} / \mathrm{ha})\end{array}$ & $\begin{array}{l}\text { Forb production } \\
(\mathrm{kg} / \mathrm{ha})\end{array}$ \\
\hline \multicolumn{3}{|c|}{ Heavily grazed pasture } \\
\hline October 1977 & & \\
\hline $\begin{array}{c}25.0^{1} \\
18.8 \\
12.6 \\
6.2 \\
0\end{array}$ & $\begin{aligned} 40 \mathrm{a}^{2} \\
31 \mathrm{a}^{2} \\
45 \mathrm{a} \\
209 \mathrm{~b} \\
418 \mathrm{c}\end{aligned}$ & $\begin{array}{rl}27 & \mathrm{a} \\
13 \mathrm{a} \\
12 \mathrm{a} \\
51 \mathrm{a} \\
542 \mathrm{~b}\end{array}$ \\
\hline $\begin{array}{c}\text { October } 1978 \\
9.0 \\
8.6 \\
7.9 \\
4.3 \\
0.2\end{array}$ & $\begin{array}{r}437 \mathrm{a} \\
416 \mathrm{a} \\
808 \mathrm{~b} \\
530 \mathrm{a} \\
1363 \mathrm{c}\end{array}$ & $\begin{array}{l}665 \text { a } \\
512 \text { a } \\
523 \text { a } \\
638 \text { a } \\
558 \text { a }\end{array}$ \\
\hline $\begin{array}{c}\text { October } 1979 \\
1.2 \\
0.8 \\
1.8 \\
0.2 \\
0.4\end{array}$ & $\begin{array}{r}254 \mathrm{a} \\
722 \mathrm{~b} \\
699 \mathrm{~b} \\
737 \mathrm{~b} \\
1014 \mathrm{c}\end{array}$ & $\begin{array}{l}668 \text { a } \\
864 \text { a } \\
525 \text { a } \\
683 \text { a } \\
889 \text { a }\end{array}$ \\
\hline $\begin{array}{l}\text { Moderately grazed } \\
\text { October } 1977\end{array}$ & & \\
\hline $\begin{array}{l}18.0^{3} \\
12.6 \\
9.3 \\
6.2 \\
0\end{array}$ & $\begin{array}{l}454 \mathrm{a} \\
486 \mathrm{a} \\
403 \mathrm{a} \\
562 \mathrm{ab} \\
646 \mathrm{~b}\end{array}$ & $\begin{array}{rl}13 & \mathrm{a} \\
3 & \mathrm{a} \\
2 & \mathrm{a} \\
25 & \mathrm{a} \\
59 & \mathrm{a}\end{array}$ \\
\hline $\begin{array}{c}\text { October } 1978 \\
9.0 \\
7.9 \\
5.7 \\
3.6 \\
0\end{array}$ & $\begin{array}{l}750 \mathrm{a} \\
1362 \mathrm{~b} \\
941 \mathrm{ab} \\
1266 \mathrm{~b} \\
1357 \mathrm{~b}\end{array}$ & $\begin{array}{rl}6 & a \\
14 & a \\
0 & a \\
4 & a \\
10 & a\end{array}$ \\
\hline $\begin{array}{c}\text { October } 1979 \\
4.0 \\
4.3 \\
2.7 \\
2.1 \\
0.2\end{array}$ & $\begin{array}{l}749 \mathrm{~b} \\
892 \mathrm{bc} \\
416 \mathrm{a} \\
806 \mathrm{~b} \\
939 \mathrm{c}\end{array}$ & $\begin{array}{r}280 \mathrm{a} \\
653 \mathrm{~b} \\
345 \mathrm{a} \\
170 \mathrm{a} \\
67 \mathrm{a}\end{array}$ \\
\hline
\end{tabular}

IOriginal mean density in the heavily grazed pasture was 25 plants $\mathbf{m}^{2}$.

${ }^{2}$ Means within a evaluation date and pasture followed by the same letter are not significantly different at $P=0.05$.

'Original mean density in the moderately grazed pasture was $19 \mathrm{plants} / \mathrm{m}^{2}$.

first year, whereas partially thinned treatments did not differ from untreated rangeland. During the second and third years all treatments originally thinned by more than $33 \%$ had greater grass production than the untreated rangeland.

Standing crop of perennial grasses generally increased at both locations during each year of the study. As noted previously, this can be attributed to rest from grazing and above-normal precipitation as well as to the thinning treatments. However, the thinning treatments, especially complete removal of broom snakeweed, provided a significant competitive advantage to perennial grasses. This was especially true in the heavily grazed pasture, where grass production in broom snakeweed-free plots far exceeded that in untreated areas after 3 years $(1014 \mathrm{~kg} / \mathrm{ha}$ vs. 254). The rapid increase in perennial grass production on the treated compared to untreated areas suggests that rangeland can improve dramatically, even if in poor condition, once broom snakeweed is eliminated. The standing crop of perennial grass in the heavily grazed pasture, which was considered to be in poor condition, was far less than the moderately grazed pasture, which was in good condition at the 
start of the study (40 vs $454 \mathrm{~kg} / \mathrm{ha}$, respectively). However, when broom snakeweed was removed at both locations, standing crop of perennial grasses was about equal after 2 years (1363 vs 1357 $\mathrm{kg} / \mathrm{ha}$ ) and was greater in the heavily grazed pasture than the moderately grazed pasture after 3 years $(1014 \mathrm{vs} 939 \mathrm{~kg} / \mathrm{ha}$, respectively).

Ueckert (1979) reported perennial grasses on shortgrass prairie were slowed a year in responding to removal or thinning of broom snakeweed if plants are initially low in vigor and broom snakeweed is thinned in the middle of the growing season (late July). The rapid increase in basal cover and standing crop of perennial grasses observed in this study suggest an advantage for removing broom snakeweed at the beginning rather than the middle of the growing season (early May). Ueckert also reported that reducing broom snakeweed by $25 \%$ or $50 \%$ did not affect production of perennial grasses. Our study agrees with this observation and suggests that at least $75 \%$ of the broom snakeweed plants in dense stands must be removed to obtain significant increases in grass production the first year.

\section{Summary and Conclusions}

Complete removal of broom snakeweed in spring 1977 resulted in a $42 \%$ increase in perennial grass production, compared to untreated rangeland, in the first growing season and $81 \%$ and $25 \%$ in the second and third years, on a pasture moderately grazed and in good range condition. On a heavily grazed pasture in poor condition, removal of broom snakeweed resulted in a more dramatic increase in perennial grass production with sideoats grama accounting for most of the increase. After the first growing seasor perennial grass production on the heavily grazed pasture increase $833 \%$ where broom snakeweed was completely removed compare to untreated rangeland, and in the second and third years $712 \%$ an $300 \%$, respectively. These data suggest the benefit of complet early-season removal of dense stands of broom snakeweed becaus of the resulting sustained yield in perennial grasses, even if broor snakeweed populations decline naturally in subsequent years.

\section{Literature Cited}

Correll, D.S., and M.S. Johnson. 1970. Manual of the vascular plants ( Texas Res. Found., Renner, Texas.

Dittberner, P.L. 1971. A demographic study of some semidesert grasslan plants. M.S. Thesis, New Mexico State Univ., Las Cruces, New Mexicr

Jameson, D.A. 1970. Value of broom snakeweed as a range indicator . Range Manage. 23:302-304.

Pieper, R.D., and G.B. Donart. 1973. Drought effects on blue gram rangelands. Livestock Feeders Report. New Mexico State Univ., La Cruces, New Mexico.

Platt, Kenneth B. 1959. Plant control-some possibilities and limitation: The challenge to management. J. Range Manage. 12:64-68.

Ragsdale. B.J. 1969. Ecological and phenological characteristics of perer nial broomweed. Ph.D. Diss. Texas A\&M Univ, College Station, Texa: $138 \mathrm{p}$.

Sperry, O.E., and E.D. Robinson. 1963. Chemical control of perennif broomweed. Texas Agr. Exp. Sta. Prog. Rep. 2273. 7 p.

Ueckert, D.N. 1979. Broom snakeweed: Effect on shortgrass forage prc duction and soil water depletion. J. Range Manage. 32:216-220.

Vallentine, J.F. 1971. Range development and improvement. Brighar Young University Press. Provo, Utah. 516 p.

\section{Membership in the Society for Range Management. . .}

is open to those engoged in or interested in the study. management, or use of range ecosystems and the intelligent use of all range resources

includes research scientists, ranchers, governmental agency administrators and technical personnel. teachers, students, and people from the business community

- provides members with two publications-one oriented to research (Journal of Range Management) and the other oriented to practical resource management (Rangelands) offers opportunities for face-to-face exchange of ideas at local, national, and intemational meetings of the Society.

Dues vary according to type of membership and geographical section. For application forms and additional information, contact the:

Executive Secretary

Sociely for Range Management

2760 West Fifth Avenue

Denver, Colorado 80204

(303) 571-0174 